\title{
OCEANIC INDICES AND THEIR RELATIONS WITH THE MONTHLY PRECIPITATION IN RIO GRANDE DO SUL STATE, BRAZIL
}

\author{
Eliane Barbosa Santos ${ }^{1}$ and Gilberto Barbosa Diniz²
}

\begin{abstract}
Climatic indices were obtained from the Sea Surface Temperature (SST) in the Atlantic and Pacific oceans, available on the website of the Earth System Research Laboratory (ESRL), which belongs to the Physical Science Division (PSD) of the National Oceanic and Atmospheric Administration (NOAA). These indices were created to represent the variations of SST in the Southwest Atlantic, Equatorial Pacific and South Pacific, with the aim of studying their influence on precipitation variability in the state of Rio Grande do Sul (RS), Brazil. The precipitation dataset was obtained from the National Institute of Meteorology - Instituto Nacional de Meteorologia (INMET - $8^{\circ}$ Distrito de Meteorologia - Porto Alegre) and State Foundation for Agricultural Research - Fundação Estadual de Pesquisas Agropecuárias (FEPAGRO). Afterwards, there were made cross-correlations between the indices, and correlations between the indices and the precipitations of the RS for the period 1948-2009. The precipitation correlations were simultaneous and lagged, with the indices preceding the precipitation up to 2 months, to determine the predictive power of the indices, and estimate the evolution of this variable in the spatiotemporal domain. The index of the Southwest Atlantic SST was not significant for the precipitation of RS in the months from November to February. The highest degree of association between the indices of the Equatorial Pacific and South Pacific with precipitation were found in November. In general, it was observed that the significant coefficients in the simultaneous correlations remained until lag 2, i.e., the SST in the Equatorial Pacific and South Pacific can be good predictors of the rain quality for the state of the RS, up to 2 months in advance.
\end{abstract}

Keywords: Equatorial Pacific, South Pacific, Southwest Atlantic, correlation analysis.

RESUMO. Foram determinados índices climáticos obtidos da Temperatura da Superfície do Mar (TSM) nos oceanos Atlântico e Pacíitico, disponíveis na página da internet do Earth System Research Laboratory (ESRL), pertencente à Physical Science Division (PSD) da National Oceanic and Atmospheric Administration (NOAA). Esses índices foram criados para representar as variações de TSM no Atlântico Sudoeste e Pacífico Equatorial e Sul, com o objetivo de estudar suas influências na variabilidade da precipitação do Estado do Rio Grande do Sul (RS). Os dados de precipitação foram obtidos do Instituto Nacional de Meteorologia (INMET, $8^{\circ}$ Distrito de Meteorologia - Porto Alegre) e Fundação Estadual de Pesquisas Agropecuárias (FEPAGRO). Posteriormente, foram realizadas correlações cruzadas entre os índices, e correlações entre os índices e as precipitações do RS para o período de 1948-2009. As correlações com as precipitações foram simultâneas e com defasagem, com os índices precedendo a precipitação em até 2 meses, para determinar o caráter preditivo do índice em questão, e estimar a evolução dessa variável no domínio espaçotemporal. 0 índice das TSM do Atlântico Sudoeste não foi significativo para as precipitações do RS nos meses de novembro a fevereiro. 0 maior grau de associação entre os índices do Pacífico Equatorial e Sul com as precipitações foi encontrado em novembro. No geral, foi observado que os coeficientes significativos nas correlações simultâneas, permaneceram até o lag 2, ou seja, as TSM do Pacífico Equatorial e Sul podem ser bons previsores da qualidade da chuva para o Estado do RS, com até 2 meses de antecedência.

Palavras-chave: Pacífico Equatorial, Pacífico Sul, Atlântico Sudoeste, análise de correlação.

\footnotetext{
1 Universidade Federal do Rio Grande do Norte, Post-graduate Program on Climate Sciences, Campus Universitário Lagoa Nova, P.0. Box 1524, 59078-970 Natal, RN, Brazil. Phone: +55(84) 3342-2479 - E-mail: elianbs@gmail.com

2Universidade Federal de Pelotas, Department of Meteorology, Campus Universitário, P.0. Box 354, 96010-900 Pelotas, RS, Brazil. Phone/Fax: +55(53) 3277-6767

- E-mail: gilberto@ufpel.tche.br
} 


\section{INTRODUCTION}

The pluvial precipitation variability is considered one of the greatest risks for agriculture in the state of Rio Grande do Sul (RS), as a whole set of activities is closely associated to the pluvial regime and these activities are severely affected by extreme events, like droughts or floods. The pluvial precipitation average values in RS present regularities along the year, but large variations along them. Berlato et al. (1995) and Ávila et al. (1996) showed that there is a large interannual variability of this variable which becomes the main limitative factor of the Spring-Summer cultures that represent about $90 \%$ of the entire grain production of RS.

To study the precipitation variability, it should be considered the ocean influence, which is a determining role for the sensible and latent heat flows, as these are the flows that provide humidity and heat for the atmosphere and are essential for the convection and precipitation patterns (Tao \& Simpson, 1991). Many recent studies provided evidences that the Atlantic and Pacific oceans play a significant role on the climatic fluctuations that occur in the South region of Brazil (Diaz et al., 1998; Grimm et al., 1998, 2000; Cardoso \& Silva Dias, 2004; Firpo, 2012). However, it is still little known about how both ocean influences are developed and how they can be explored to improve the climatic prognostic.

In this context, one of the most important variability scales is the interannual. Most of the atmosphere variability is related to the tropical oceans and the most important mode of the interannual variability of the ocean atmosphere system is the El Niño-Southern Oscillation (ENSO) (Kayano \& Andreoli, 2007). The ENSO phenomenon effects are observed in global scale and mainly alter the pluviometric and thermic regime in many regions of the world (Ropelewski \& Halpert, 1987; Kiladis \& Diaz, 1989), including RS, with a strong signal (Firpo, 2012).

The ENSO is an oceanic-atmospheric phenomenon that, when the ocean interacts with the atmosphere, modifies the field of atmospheric pressure at sea level and the wind field over the Equatorial Pacific, changing their patterns in the regional and global scales. The oceanic component is characterized by the Sea Surface Temperature (SST) change in the Equatorial region of the Pacific Ocean and presents two distinctive phases, called El Niño and La Niña.

Besides ENSO, other SST patterns also affect the climate variability in RS. In this context, it is noteworthy the importance of the Atlantic, specially the Southwest Atlantic (SWA). The SWA stands out for the proximity to the RS state, extending along its east coast and being the route of the transient systems that affect it (Pezzi et al., 2009). It is also one of the most energetic ocean zones (Pezzi \& Souza, 2009) as it is a cyclogenetic region
(Gan \& Ra0, 1991), where the Brazil-Malvinas confluence occurs (Gordon, 1989), and an area where there is the presence of the South Atlantic Convergence Zone (SACZ) (Kousky, 1988).

According to Diaz et al. (1998), SST positive (negative) anomalies in the SWA are associated to precipitation positive (negative) anomalies in the extreme south of Brazil and Uruguay. However, Haylock et al. (2006) suggested that the SWA SST do not present a direct relation to the precipitation extreme events occurred over South America and Brazil.

The Equatorial Pacific SST during La Niña events, regardless the year season, are significantly associated to the SST below the normal in the SWA. During El Niño events, significantly influences with temperatures above the normal in the SWA were observed in Summer (simultaneous) and in Autumn (1 quarter lagged) (Silva, 2001).

Soppa et al. (2011) observed ENSO influences over the thermic oscillations in the SWA. The results indicate a statistically expressive time lagged correlation between ENSO and thermal anomalies in the SWA, but without a direct association between El Niño (La Niña) warm (cold) events and positive (negative) SST anomalies. In general, the ENSO warm phase may cause an excess of precipitation in $\mathrm{RS}$, and the opposite is expected during the ENSO cold phase. Grimm et al. $(1998,2000)$ showed that the El Niño and La Niña events significantly influence the seasonal precipitation in the south region of Brazil, specially during the Spring and Autumn months, and, in the year after the ENSO warm events, the precipitation anomalies may be influenced by the SWA SST.

The South Pacific SST may also affect the precipitation in RS. According Cardoso (2005), the South Pacific SST anomalies, in the South Pacific Convergence Zone (SPCZ) region, may act as forcing and directly affect the precipitation regimes in the South and Southeast of Brazil.

The precipitation behavior analysis may help in the diagnosis of extreme precipitation events and contribute to a better strategic planning; minimizing then the risk of occurring loses, especially in the productive sector (particularly those related to agriculture, generation and distribution of electric power industry). Thus, the purpose of this paper is to study the influence of indices obtained from the Pacific and Atlantic ocean SST in the pluvial precipitation variability in the state of the RS and to analyze the possibility of the pluvial precipitation predictability with some months in advance.

\section{METHODOLOGY Datasets}

The monthly precipitation dataset was obtained from the National Institute of Meteorology - Instituto Nacional de Meteorologia 


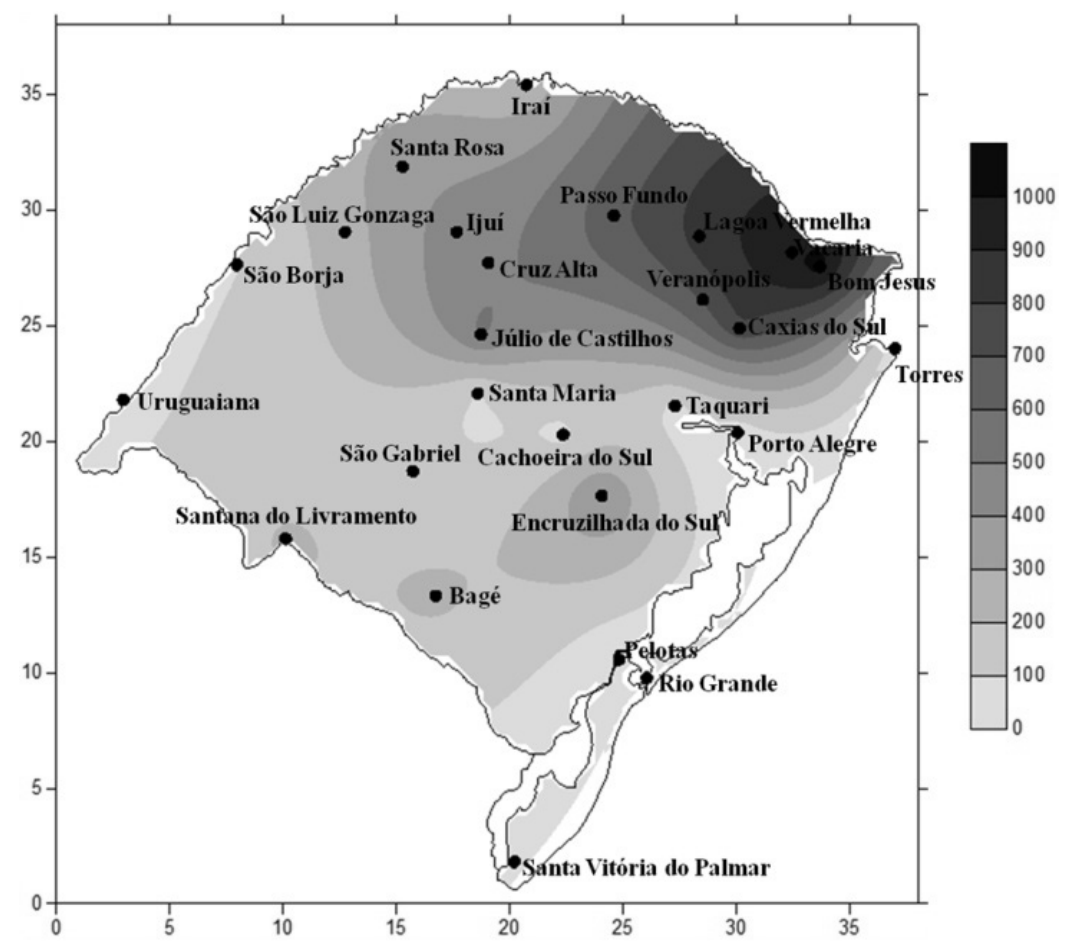

Figure 1 - Spatial distribution and altitude (grey scale) of the meteorological stations of the state of the RS used in this paper.

(INMET - $8^{\circ}$ Distrito de Meteorologia - Porto Alegre) and State Foundation for Agricultural Research - Fundação Estadual de Pesquisas Agropecuárias (FEPAGRO). These data are consistent and the failures were filled up using statistical techniques, according to the methodology proposed by Diniz (2002). It was used as a criterion to choice the stations, the availability and uniformity of long time series data, in the corresponding period from 1948 to 2009. As a result, 26 stations were selected (Fig. 1), distributed in the state of the RS.

Besides the precipitation dataset, the SST data, spaced in a $2.0^{\circ} \times 2.0^{\circ}$ grid, were used for both oceans, Atlantic and Pacific. These data are available at the site of the Earth System Research Laboratory (ESRL), which belongs to the Physical Science Division (PSD) of the National Oceanic and Atmospheric Administration (NOAA).

\section{Methods}

To represent the variations of SST in the Southwest Atlantic, Equatorial Pacific and South Pacific, SST monthly indices were determined. Figure 2 shows the regions obtained for the indices calculus.

Southwest Atlantic Index (SWAI): it was calculated using the Southwest Atlantic region between $20^{\circ} \mathrm{S}$ to $40^{\circ} \mathrm{S}$ and $20^{\circ} \mathrm{W}$ to $60^{\circ} \mathrm{W}$. This region was chosen based on the regions used in previous papers (Sansigolo et al., 2004; Cardoso, 2005; Pezzi et al., 2009; Firpo, 2012).

Equatorial Pacific Index (EPI): the most used region for research and monitoring of the Equatorial Pacific SST is the Niño 3.4 region (Bunge \& Clarke, 2009). Niño 3.4 is, in general, chosen due to, in this region, the SST variability possesses a strong effect on the displacement of the Western Pacific precipitation which in turn modifies the location of the heating source that controls/modulates the general atmospheric circulation. Thus, the index was obtained in the region corresponding to Niño 3.4, between $5^{\circ} \mathrm{S}$ to $5^{\circ} \mathrm{N}$ and $120^{\circ} \mathrm{W}$ to $170^{\circ} \mathrm{W}$.

South Pacific Index (SPI): it was determined using the South Pacific region between $20^{\circ} \mathrm{S}$ to $40^{\circ} \mathrm{S}$ and $130^{\circ} \mathrm{W}$ to $170^{\circ} \mathrm{W}$, the area corresponding to SPCZ (Barros \& Silvestri, 2002; Firpo, 2012).

The indices were elaborated for the 1948 to 2009 period, calculating the average and the standard deviation of the SST series of each region. These deviations were standardized and constituted index time series, that is, to determine the indices it was used the formula:

$$
S I=\frac{x_{i j}-\overline{x_{j}}}{s_{j}}
$$

where: $S I=$ standardized index, $x_{i j}=$ the value found for a given year $(i)$ and month $(j), \overline{x_{j}}=$ the average value for a given month $(j)$ and $s_{j}=$ standard deviation for a given month $(j)$. 


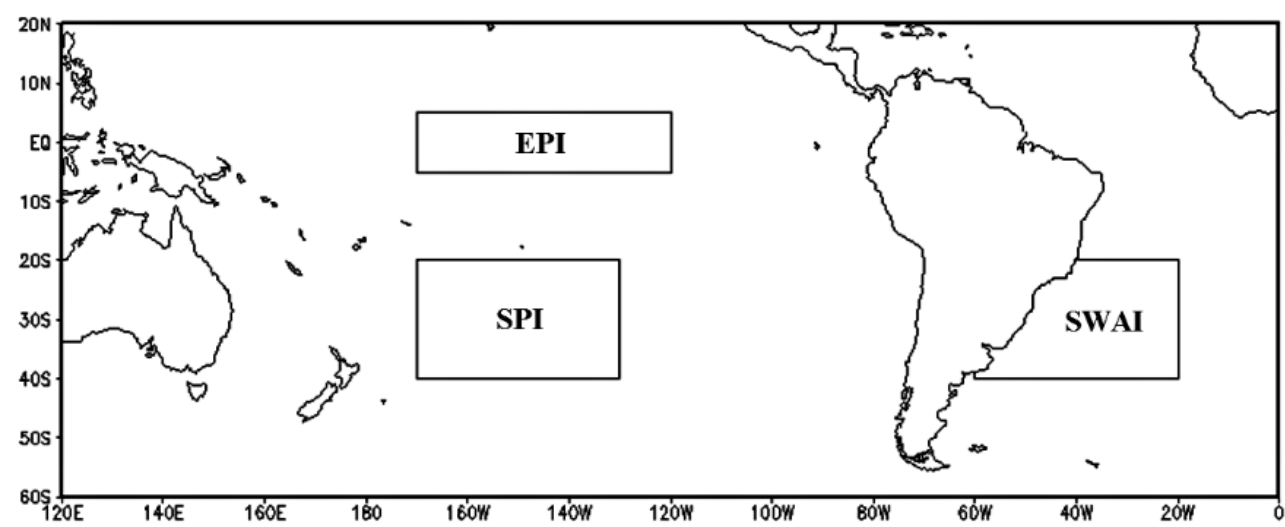

Figure 2 - Spatial domain of the used data, indicating the SST time series regions for the index calculus.

To verify the possibility of trend occurrence in the studied time series (indices obtained from the SST and the precipitation series), it was used the Mann-Kendall (MK) non-parametric statistical test, according to the methodology proposed by Sneyers (1992). Goossens \& Berger (1986) assert that the Mann-Kendall test is the most appropriate method to analyze the climate changes in climatologic series. However, it is needed to highlight that the significative presence of seasonalities or autocorrelations affects the sensitivity of this method (Hamed \& Rao, 1998; Bayazit \& Önöz, 2007). The presence of these two factors amplify the probability of detecting false increasing trends (Blain, 2010).

The MK test considers that, in case of a time series stability, the value succession occurs independently, and the probability distribution must always remain the same (random and simple). Among the benefits of using this method, it is the capacity to identify the trend direction and starting point. Besides, the data do not need to belong to a specific distribution, and its result is not affected by extreme values, since the calculus is based on the signal and not on the difference values of the test variable (Önöz \& Bayazit, 2003).

The time series randomness was evaluated by the non-test of sequences of adherence to the normal distribution, called runs tests, which checks whether the elements of the series are independent of each other. Was adopted a 5\% significance level for the test. The non rejected series in these tests were submitted to the MK test. For the rejected series in the Runs Tests, it was used the Seazonal Mann-Kendall (SMK) test, the method proposed by Hirsch et al. (1982) and Hirsch \& Slack (1984) with the purpose to adapt the MK for autocorrelated series, as well as to deal with difficulties imposed by possible seasonalities.

Considering the $5 \%$ significance level, significative trends were removed from the time series, making successive differences of the original series.
To verify the dependence between the Pacific and Atlantic ocean SST, simultaneous and lagged correlations, among the SST indices, were performed. The SST indices were also used to obtain the monthly correlation with the standardized precipitation of the 26 meteorological stations of RS, in the months from November to February, which are considered important months for the grain production in RS. These climatic indices were correlated with the precipitation in the same months, that is, with lag 0, the November pluvial precipitation with the November index and so on for the other months. These simultaneous analyses are valid to identify areas in the region that present greater relation with the index, but do not indicate a pluvial predictability in these months. For this reason, correlations with lags were also analyzed, with indices up to 2 months ahead, i.e., preceding the precipitation, since an aspect that there is not a general agreement yet is which lag time, or lag, would be in the response that the precipitation would present, if it occurs SST changes in the Pacific and/or Atlantic.

For the correlation calculus, it was used the Pearson correlation method, known as ordinary correlation or linear correlation, which is a simple and efficient tool to estimate the relationship ranking among any variables.

The correlation coefficient significance level was defined using the Student's t test.

\section{RESULTS AND DISCUSSION}

In the study of the precipitation series of the 26 used station, the trend (positive) was significant (at $5 \%$ level) for 15 . For the series of the indices obtained from the SST, all of them showed significant trends (positive).

After removing the trends, the time series were used to obtain relations among them. To show the relation between the SST of the Pacific and Atlantic oceans, cross correlations among the indices (SWAI, EPI and SPI) were performed. In Figure 3 it can be 

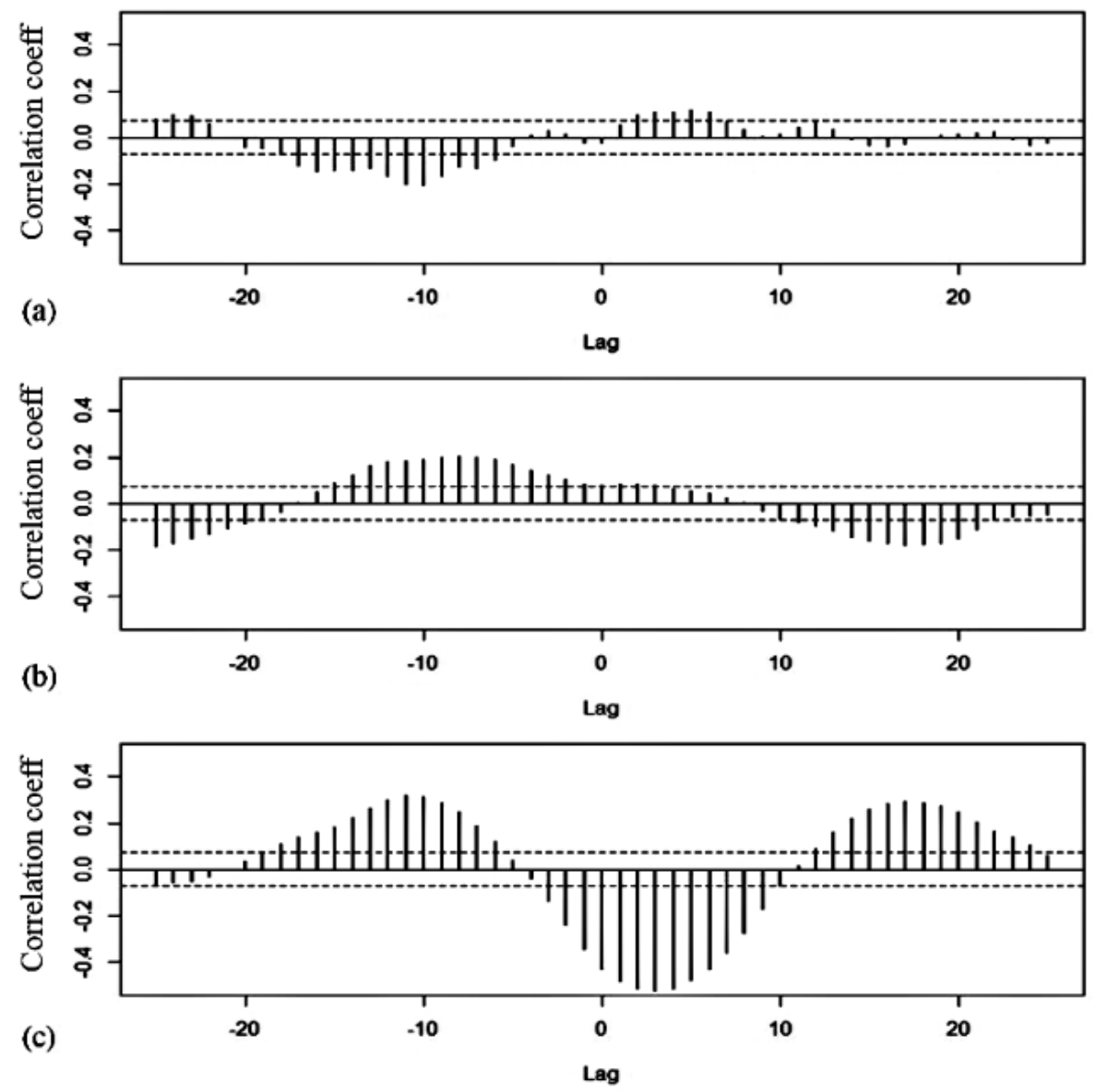

Figure 3 - Cross-correlation among the indices: (a) SPI and SWAl; (b) EPI and SWAI; and (c) EPI and SPI.

noticed that the SWAI showed low coefficients with the EPI and SPI indices. Its values in the simultaneous and lagged correlations were about -0.1 to 0.17 . The indices that showed greater coefficients of simultaneous and lagged correlation were the EPI and SPI. In the first EPI and SPI correlations with lags (lag -4 to lag 10), the values were negative, showing an inverse relation among the indices, that is, the Equatorial Pacific SST anomalies were positive (negative) when the South Pacific SST anomalies were negative (positive).

In the positive lags, the EPI is lagged in relation to the SPI and its highest coefficient was about -0.49 in the lags 2, 3 and 4 . In the negative lags, the EPI is ahead in relation to the SPI and its highest coefficient was about 0.29 in lags -10 and -11 .

In Figures 4, 5 and 6 there is a spatial distribution of the correlation coefficients, among the precipitations and the SWAI, EPI and SPI indices, respectively. The shade highlights, through Student's $t$ test, the regions with statistically expressive correlations, at $5 \%$ significance level.
Although the SWAI represents a region near the state of the RS and is also the route of the transient systems that affect it (Pezzi et al., 2009), it was not representative for the precipitations in RS in the months from November to February, showing few significant coefficients (Fig. 4). The best results were found in the simultaneous correlations in December and January.

In the correlations of the precipitation series with the EPI (Fig. 5), the significant coefficients found in the simultaneous correlations remained until lag 2. All significant coefficients were positive, indicating that SST anomalies in the IPE influence the precipitation in RS in a direct way. As the EPI values are in Niño 3.4 region, then the EPI positive and negative values are, in general, indicators of the occurrence of El Niño and La Niña events, respectively, attesting, in principle, that it rained more (less) in El Niño (La Niña) years in this regions.

For agriculture in RS, El Niño and La Niña winds, besides losses, may cause benefits. Berlato et al. (2005) found a strong trend of El Niño to favor the corn cultivation, promoting high 

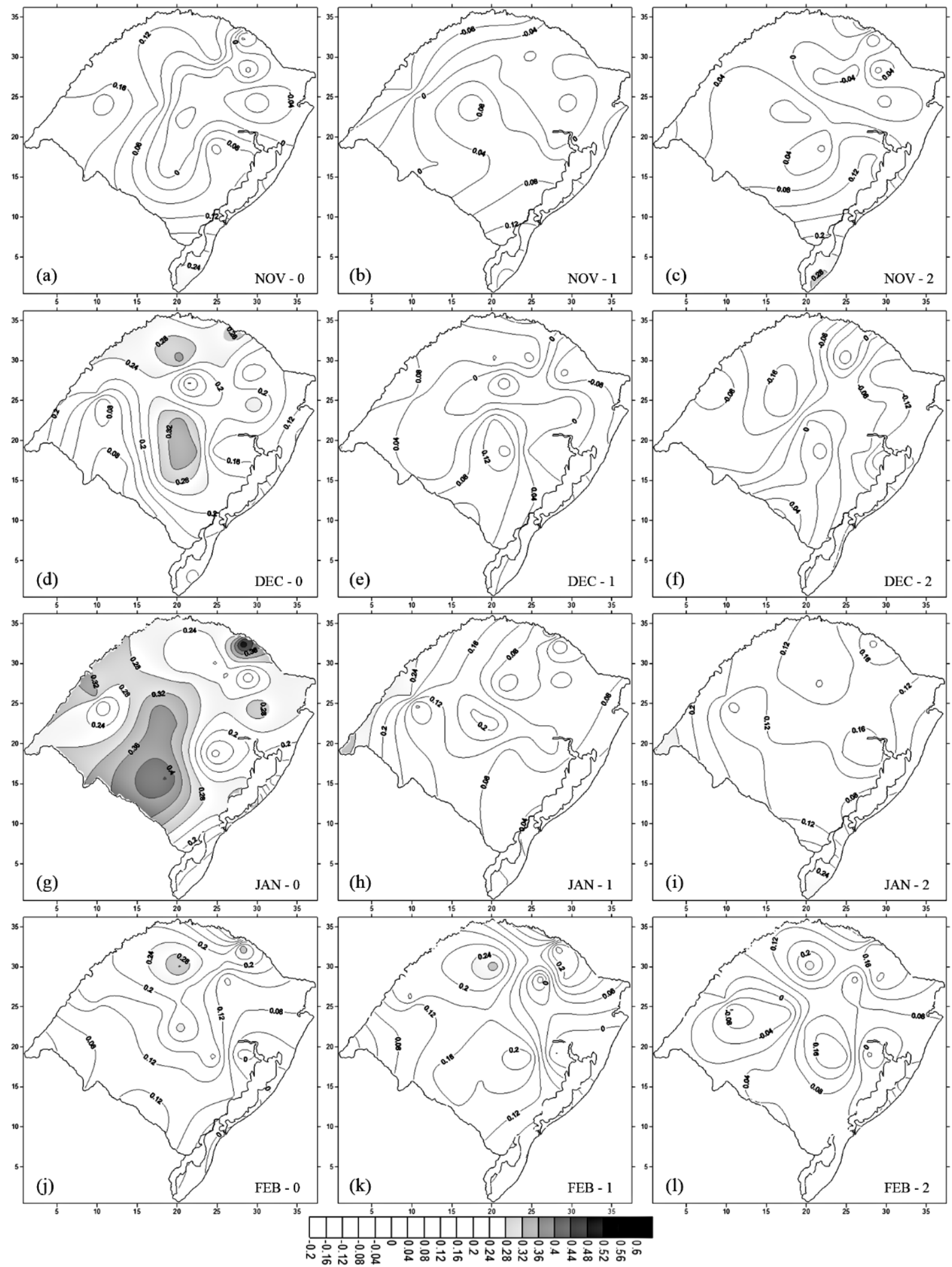

Figure 4 - Correlation between the monthly precipitation of the state of the RS and the SWAI, for the months from November to February, with lags from 0 up to 2 months. 

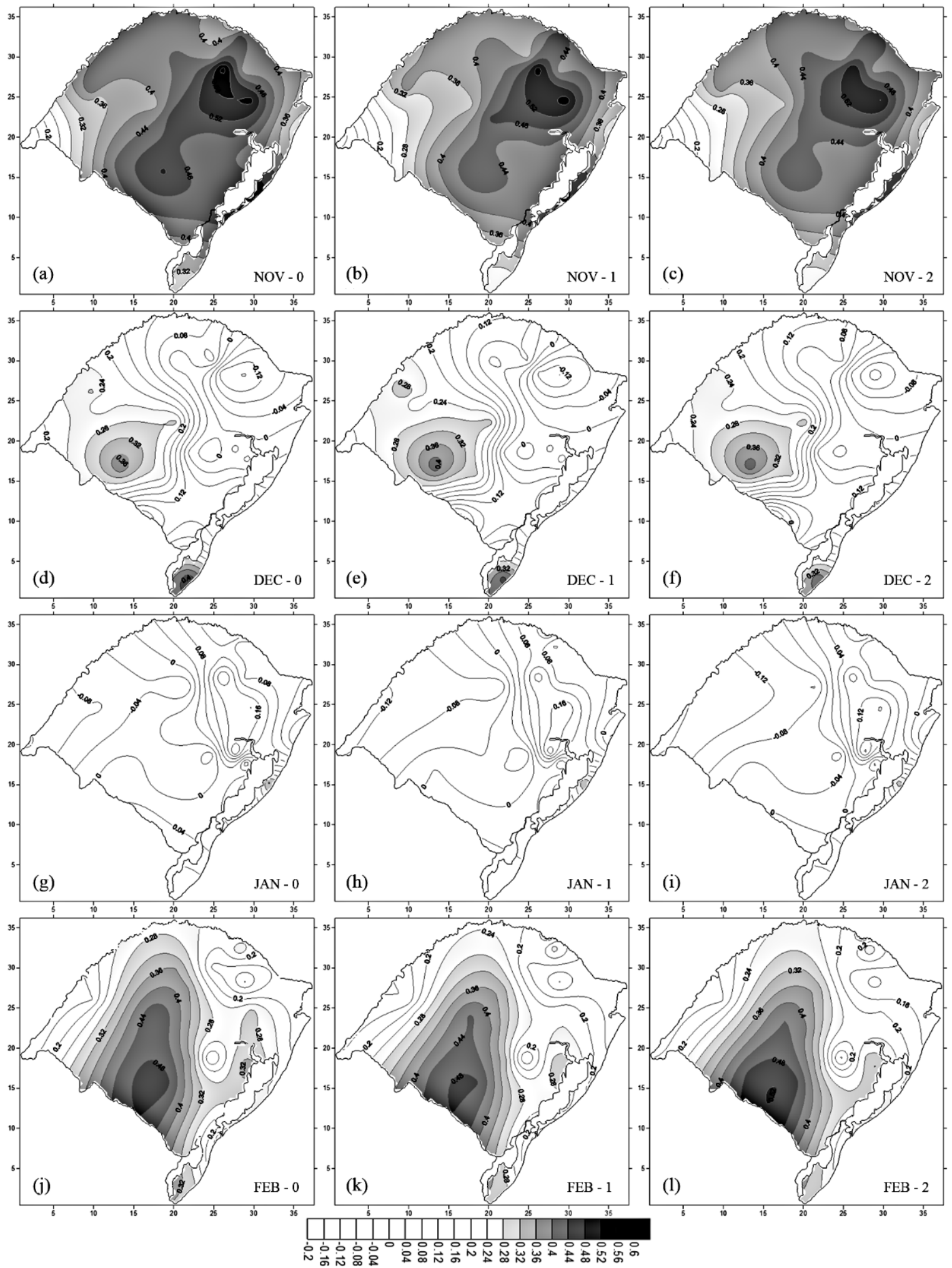

Figure 5 - Correlation between the monthly precipitation of the state of the RS and the EPI, for the months from November to February, with lags from 0 up to 2 months. 

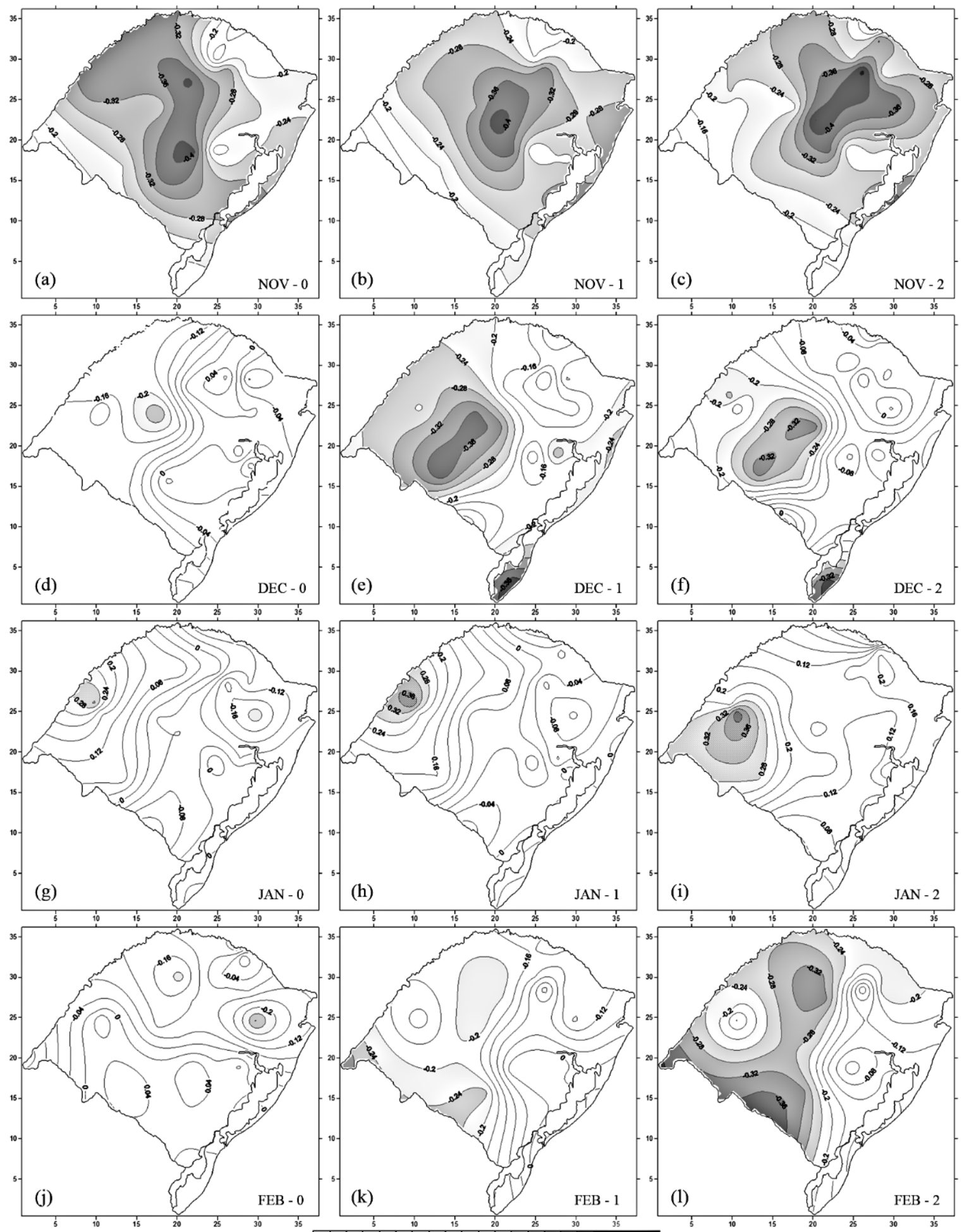

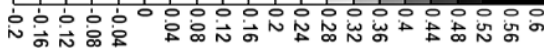

Figure 6 - Correlation between the monthly precipitation of the state of the RS and the SPI, for the months from November to February, with lags from 0 up to 2 months. 
productivity, and, in La Niña years, found high frequency of low productivity. In El Niño occurrence, in general, the Summer cultures (soya and corn, particularly) are benefitted, because there are not water shortages (Cunha, 1999). Thus, the significative coefficients found in the correlations between the RS precipitations and the EPI (Fig. 5) are important for handling many cultivations.

Although the ENSO influence occurs during all period of these event action, there are periods in the year that are more affected by the ENSO phases, and the beginning of Summer (October, November and December) is one of them. November was the month that presented the best results of the correlations between the precipitations and the EPI, and 1\% significative values were found in almost all RS regions. These results are in accord with Lopes et al. (2007) that found the greatest coefficients of correlation among the precipitations in the state of the RS and the Niños region SST and the ENSO multivariate index, in October-November and November-December quarters.

Among the four studied months, January was the sole month that did not present any region with significative coefficients, in the simultaneous correlations of the EPI with precipitation, as well as in the lagged correlations of the EPI with precipitation.

Like the correlations performed with the EPI, the SPI also presented its greatest coefficients in November (Fig. 6). The significant coefficients in November were negative in the simultaneous and lagged correlations, that is, the South Pacific SST anomalies were positive (negative) when the precipitation anomalies were negative (positive). As the EPI and SPI indices showed a significative inverse relation, and the EPI is very representative for the precipitation of RS in November, it was already expected that in November the correlations between the SPI and the precipitations were negative.

The IPS was defined using the area corresponding to SPCZ. This Convergence Zone occurs during the ENSO cold (La Niña) and neutral phases, and in the warm phase (El Niño) this convergence zone disappears, i.e., in the simultaneous occurrence of the La Niña and South Pacific positive anomalies, the possibilities of occurring negative anomalies precipitation increase.

In the other months (December, January and February), the IPS with precipitation correlation showed significant coefficients in small regions, and these regions expanded with the lag increase. In December and February, all correlation values were negative, however, in January, regions with significant positive coefficients were found.

The results found in the correlations between the precipitations and the SPI attest the results of Cardoso (2005), that the South Pacific SST anomalies may affect the precipitation regime in the state of the RS.

\section{CONCLUSIONS}

The simultaneous and with lag correlations among the indices obtained from the SST indicate that there is a dependence relation between the patterns of the Equatorial Pacific and South Pacific SST.

In the correlations between the SST indices and the state of the RS precipitation, the lowest correlation coefficients were found in the SWAI. This index presented few significative coefficients, and it is not representative for RS precipitation in the months from November to February in simultaneous and up 2 month lagged correlations. However, this index may be representative in other months and/or in correlations with greater lags.

Among the four studied months, November was the month that showed the greatest correlation coefficients with the IPE and IPS, that is, the precipitation in RS seems to have the highest degree of association with the Pacific anomalies in November.

The SST variations in the Equatorial and South Pacific ocean produce noticeable impacts in the precipitation of $R S$, showing correlations that exceed the confidence level of 95 and $99 \%$ in many regions.

The EPI and SPI indices may be good predictors of the rain quality for the state of the RS, with up to 2 months in advance. And any index that is representative of the SST variations may be used like a potential predictor.

The found results may serve to reduce losses or to improve the use of favorable climatic conditions for handling many cultures. It is worth noting that the SST anomaly impacts over agriculture depend on the kind of culture.

\section{REFERENCES}

AVILA AMH, BERLATO MA, SILVA JB \& FONTANA DC. 1996. Probabilidade de ocorrência de precipitação pluvial mensal igual ou maior que a evapotranspiração potencial para a estação de crescimento das culturas de primavera-verão no Estado do Rio Grande do Sul. Pesquisa Agropecuária Gaúcha, Porto Alegre - RS, 2(2): 149-154.

BARROS VR \& SILVESTRI GE. 2002. The relation between sea surface temperature at the subtropical south-central Pacific and precipitation in southeastern South America. J. Climate, 15(3): 251-267.

BAYAZIT M \& ÖNÖZ B. 2007. To prewhiten or not to prewhiten in trend analysis? Hydrol. Sci. J., 52(4): 611-624, doi: 10.1623/hysj.52.4.611.

BERLATO MA, FONTANA DC \& BONO L. 1995. Tendência temporal da precipitação pluvial anual no Estado do Rio Grande do Sul. Rev. Bras. Agrometeorologia, Santa Maria - RS, 3: 111-113.

BERLATO MA, FARENZENA H \& FONTANA DC. 2005. Associação entre El Niño oscilação Sul e a produtividade de milho no Estado do Rio Grande do Sul. Pesquisa Agropecuária Brasileira, 40: 423-432. 
BLAIN GC. 2010. Detecção de tendências monótonas em séries mensais de precipitação pluvial do estado de São Paulo. Bragantia, Campinas SP, 69(4): 1027-1033

BUNGE LA \& CLARKE J. 2009. A verified estimation of the EI Niño index Niño-3.4 since 1877. J. Climate, 22: 3979-3992.

CARDOSO A0. 2005. Relações entre a TSM nos oceanos Atlântico e Pacífico e as condições climáticas nas Regiões Sul e Sudeste do Brasil. Doctorate thesis on Meteorology, Instituto de Astronomia Geofísica e Ciências Atmosféricas, Universidade de São Paulo, USP, São Paulo SP, Brazil, 158 pp.

CARDOSO AO \& SILVA DIAS PL. 2004. Identificação de trimestres extremos no regime Pluviométrico do Sul e Sudeste do Brasil e relação com anomalias de TSM. Rev. Bras. Meteorol., 19(1): 149-162.

CUNHA GR. 1999. El Niño - Oscilação Sul e perspectivas climáticas aplicadas no manejo de culturas no Sul do Brasil. Rev. Bras. Agrometeorologia, Santa Maria - RS, 7(2): 277-284.

DIAZ AF, STUDZINSKI CD \& MECHOSO CR. 1998. Relationships between precipitation anomalies in Uruguay and southern Brazil and sea surface temperature in the Pacific and Atlantic oceans. J. Climate, 11(2): 251-271.

DINIZ GB. 2002. Preditores visando à obtenção de um modelo de previsão climática de temperaturas máxima e mínima para regiões homogêneas do Rio Grande do Sul. Doctorate thesis on Agrometeorology, Post-graduate Program on Phytotechnics, Universidade Federal do Rio Grande do Sul, UFRGS, Porto Alegre - RS, Brazil, 196 pp.

FIRPO MAF. 2012. Influência Remota da TSM dos Oceanos Pacífico e Atlântico e da Oscilação Antártica na Variabilidade Climática interanual no Rio Grande do Sul e suas inter-relações. Doctorate thesis on Meteorology, Instituto Nacional de Pesquisas Espaciais, São José dos Campos - SP, Brazil, 200 pp.

GAN MA \& RAO VB. 1991. Surface Cyclogenesis over South America. Mon. Weather Rev., 119(5): 1293-1302, doi:

10.1175/1520-0493(1991)119<1293:SCOSA > 2.0.C0;2.

GO0SSENS CH \& BERGER A. 1986. Annual and Seasonal Climatic Variation over the Northern Hemisphere and Europe during the Last Century. Ann. Geophys., 4: 385-400.

GORDON AL. 1989. Brazil-Malvinas Confluence-1984. Deep Sea Res., 36(3): 359-405.

GRIMM AM, FERRAZSET \& GOMES J. 1998. Precipitation anomalies in Southern Brazil associated with El Niño and La Niña events. J. Climate, 11(11): 2863-2880, doi:

10.1175/1520-0442(1998)011<2863:PAISBA > 2.0.C0;2.

GRIMM AM, BARROS VR \& DOYLE ME. 2000. Climate variability in Southern South America associated with El Niño and La Niña events.
J. Climate, 13: 35-58, doi:

10.1175/1520-0442(2000)013<0035:CVISSA>2.0.C0;2.

HAMED KH \& RAO AR. 1998. A modified Mann-Kendall trend test for autocorrelated data. J. Hydrol., 204: 182-196, doi: 10.1016/S00221694(97)00125-X.

HAYLOCK MR, PETERSON TC, ALVES LM, AMBRIZZI T, ANUNCIAÇÃO YMT, BAEZ J, BARROS VR, BERLATO MA, BIDEGAIN M, CORONEL G, CORRADI V, GARCIA VJ, GRIMM AM, KAROLY D, MARENGO JA, MARINO MB, MONCUNILL DF, NECHET D, QUINTANA J, REBELLO E, RUSTICUCCI M, SANTOS JL, TREBEJO I \& VINCENT LA. 2006. Trends in Total and Extreme South American Rainfall in 1960-2000 and Links with Sea Surface Temperature. J. Climate, 19: 1490-1512, doi: 10.1175/JCLI3695.1.

HIRSCH RM \& SLACK JR. 1984. A nonparametric trend test for seasonal data with serial dependence. Water Resour. Res., 20(6): 727-732, doi: 10.1029/WR020i006p00727.

HIRSCH RM, SLACK JR \& SMITH RA. 1982. Techniques of trend analysis for monthly water quality data. Water Resour. Res., 18(1): 107-121, doi: 10.1029/WR018i001p00107.

KAYANO MT \& ANDREOLIRV. 2007. Relations of South American summer rainfall interannual variations with the Pacific Decadal Oscillation. Int. J. Climatol., 27: 531-540, doi: 10.1002/joc.1417.

KILADIS GN \& DIAZ HF. 1989. Global climate anomalies associated with extremes in the Southern Oscillation. J. Climate, 2: 1069-1090, doi: 10.1175/1520-0442(1989)002<1069:GCAAWE>2.0.C0;2.

KOUSKY VE. 1988. Pentad outgoing longwave radiation climatology for the South American sector. Rev. Bras. Meteorol., 3: 217-231.

LOPES FZ, DINIZ GB \& MARQUES JR. 2007. Relação entre o Multivariate Enso Index (MEI) e a TSM das Regiões dos Niños com a Precipitação em Regiões Homogêneas do Estado do Rio Grande do Sul. Anuário do Instituto de Geociências - UFRJ, 30(2): 11-22.

ÖNÖZ B \& BAYAZIT M. 2003. The Power of Statistical Tests for Trend Detection. Turk. J. Eng. Environ. Sci., 27: 247-251.

PEZZI LP \& SOUZA RB. 2009. Variabilidade de Mesoescala e interação oceano-atmosfera no Atlântico Sudoeste. In: CAVALCANTI IFA, FERREIRA NJ, JUSTI DA SILVA MGA \& SILVA DIAS MAF. Tempo e Clima no Brasil. São Paulo: Ed. Oficina de Textos, Cap. 24: 387-405.

PEZZI LP, SOUZA RB, ACEVEDO 0, WAINER I, MATA MM, GARCIA CAE \& CAMARGO R. 2009. Multiyear measurements of the Oceanic and Atmospheric Boundary Layers at the Brazil-Malvinas Confluence Region. J. Geophys. Res., 114, D19103, doi: 10.1029/2008JD011379.

ROPELEWSKI CF \& HALPERT MS. 1987. Global and regional scale precipitation patterns associated with the El Niño/Southern Oscillation. Mon. Weather Rev., 115: 1606-1626, doi:

10.1175/1520-0493(1987)115<1606:GARSPP > 2.0.C0;2. 
SANSIGOLO CA, PEREIRA CS \& SILVA IR. 2004. Relações entre as precipitações regionais no Sul do Brasil e as temperaturas da superfície dos oceanos Atlântico e Pacífico. Rev. Bras. Meteorol., 19(1): 5-11.

SILVA IR. 2001. Variabilidade sazonal e interanual das precipitações na região Sul do Brasil associadas às temperaturas dos oceanos Atlântico e Pacífico. Master dissertation on Meteorology, Instituto Nacional de Pesquisas Espaciais, São José dos Campos - SP, 98 pp.

SNEYERS R. 1992. On the use of Statistical Analysis for the Objective
Determination of Climatic Change. Meteorol. Zeitschrift. 1: 247-256.

SOPPA MA, SOUZA RB \& PEZZI LP. 2011. Variabilidade das anomalias de temperatura da superfície do mar no Oceano Atlântico sudoeste e sua relação com o fenômeno El Niño-Oscilação Sul. Rev. Bras. Meteorol., 26(3): 375-391.

TAO WK \& SIMPSON J. 1991. Numerical simulation of a subtropical squall line over Taiwan Strait. Mon. Weather Rev., 119: 2699-2723.

Recebido em 13 setembro, 2012 / Aceito em 21 agosto, 2014

Received on September 13, 2012 / Accepted on August 21, 2014

\section{NOTES ABOUT THE AUTHORS}

Eliane Barbosa Santos. Bachelor degree in Meteorology at Universidade Federal de Alagoas, UFAL (2005-2008), Master degree in Meteorology at Universidade Federal de Pelotas, UFPel (2009-2010). Currently, is a Ph.D. student in Climate Sciences at Universidade Federal do Rio Grande do Norte, UFRN. Has experience in Geosciences with emphasis on Climatology, Statistical Climatology and Extreme Rainfall.

Gilberto Barbosa Diniz. Bachelor degree in Meteorology at Universidade Federal da Paraíba, UFPB (1979), Master degree in Meteorology at UFPB (1994), Doctorate degree in Agrometeorology at Universidade Federal do Rio Grande do Sul, UFRGS (2002). Associated professor IV of the undergratuate and post-graduate courses at Department of Meteorology, Universidade Federal de Pelotas, UFPel. Has experience in Geosciences with emphasis on Climatology, Statistical Climatology and Physical Meteorology. 